\title{
The Dilemma of Colonial Hybridity in Brian Friel's Translations
}

\section{Chu He}

\section{(2) OpenEdition \\ 1 Journals}

\section{Electronic version}

URL: http://journals.openedition.org/etudesirlandaises/1818

DOI: 10.4000/etudesirlandaises.1818

ISSN: 2259-8863

\section{Publisher}

Presses universitaires de Caen

\section{Printed version}

Date of publication: 30 June 2010

Number of pages: 117-129

ISSN: 0183-973X

\section{Electronic reference}

Chu He, "The Dilemma of Colonial Hybridity in Brian Friel's Translations », Études irlandaises [Online], 35-1 | 2010, Online since 30 September 2012, connection on 21 December 2020. URL : http:// journals.openedition.org/etudesirlandaises/1818; DOI : https://doi.org/10.4000/etudesirlandaises. 1818

This text was automatically generated on 21 December 2020.

\section{cc) (†) (-)}

Études irlandaises est mise à disposition selon les termes de la Licence Creative Commons Attribution - Pas d'Utilisation Commerciale - Partage dans les Mêmes Conditions 4.0 International. 


\title{
The Dilemma of Colonial Hybridity in Brian Friel's Translations
}

\author{
Chu He
}

1 Since its debut in 1980, Translations has been read as a play about Ireland's historical transformation from a predominantly Gaelic nation to an Anglicized one in the midnineteenth century. Such a conventional approach to Translations, however, is limited, for the emphasis on the drastic change in Irish society overlooks the underlying coexistence of English and Irish cultures in the play. Translations depicts not only a dying Gaelic civilization under English cultural colonization but also a hybridized Ireland and adulterated people in the transitional time. Colonial Ireland is actually inscribed in a dual state, for the Irish names, schools, and language still persist despite the sweeping Anglicization, and the Irish people are also stuck in an irresoluble dilemma their hybridity poses to them. As typical to colonial situation, their hybridity speaks more to the differences and contradictions than similarities and connections between two cultures and peoples. Unable to strip off their double cultural holdings or negotiate the two oppositional traditions, the characters cannot come to terms with their adulterated selves. As a result, they are condemned to an irreconcilable struggle in an eternal borderland. In this sense, colonization has made hybridity inevitable and dead-end at the same time.

2 As a play set in 1833 Ballybeg, Translations dramatizes the transformation brought by the Ordnance Survey and National School System, which precipitate an irrevocable Anglicization process in traditional Irish society. Subject to the map-making project, Ballybeg is surveyed and renamed by English soldiers - its official place names are changed from Irish into English. Such a cultural deprivation is deepened by the National School System - Hugh's hedge school will be supplanted by the new national school, in which English will replace Irish as the language of instruction. Ballybeg, the microcosm of Ireland, is thus faced with a radical change. The imminent danger of losing one's own language, culture, and tradition plunges Ireland into an unprecedented identity crisis. Given the thematic importance of the enforced social transition in the play, it is not 
surprising that most criticism of the play centers on the inevitable loss of Gaelic civilization. Ulf Dantanus summarizes the play as one that "describes the beginning of the final linguistic and cultural take-over of Ireland by the British Empire and signals the virtual extinction of Gaelic civilization" ${ }^{1 "}$. Tony Corbett echoes his opinion: "It dramatizes the last gasp of Gaelic Ireland, the surrender of the peasantry to cultural colonization'"." Richard Pine also calls the play "a lament for a lost civilization or culture ${ }^{3 "}$.

While the endangered Gaelic culture and the irrevocable change of Irish society greatly shape the interpretation of the play, it is time to ask whether such an overemphasis on transformation has conveniently overlooked other, latent, facts. I am not arguing against the loss of Gaelic civilization, but I am interested in those ambiguous, contrary undercurrents beneath the overwhelming Anglicization of Ireland. Those bits and pieces that are omitted in the critical consensus concerning the play can be quite telling of the real, complicated situation in colonial Ireland. They reveal a paradoxical phenomenon of change and constancy, displacement and concomitance, for the Gaelic traditions still lurk under the English cultural domination, and the characters are actually living with the clashing yet mingling English and Irish cultures. Therefore, Translations not only depicts a dying Gaelic civilization under English colonization but also portrays a hybridized Ireland and adulterated people in the transitional time.

4 To begin with, Friel's Ballybeg is by no means a pure, unitary society. The Irish people's multilingualism is highlighted throughout the play - Jimmy is fluent in Greek; Hugh and Manus are masters of Latin, Greek, and English; other characters also know some of these languages, mostly a result of their hedge school education. Irish civilization is thus shown to be a conglomeration of foreign and native cultures, even to the extent that "ancient Irish culture [is] overwhelmed by... classical literature" ${ }^{4}$. Like the mixture of different languages, different people also intermingle in Ballybeg. The transgressive love between Maire and Yolland crosses the border of nation, language, and culture. The exogamy between Jimmy and the Greek Goddess Athene, though in imagination only, also breaks the boundary between man and deity. Those heterogeneous couples overturn the conception of purity through their hybrid combinations. Unlike those fruitless exogamous relationships, Nellie Ruadh's sexual transgression produces an illegitimate baby, whose presence is quite common in Friel's other plays such as Aristocrats, The Gentle Island, and Dancing at Lughnasa. Like the illegitimate baby who cannot claim a genuine, pure lineage to its father, anglicized Ireland is also a bastard descendent from its pristine Celtic origin. If Irish nationalists try to legitimize and purify the adulterated Ireland, Friel uses the illegitimate baby to disrupt such an identity construction, and exposes the hybrid, impure nature of colonized Ireland. In this way, the references to the baby's baptism in the beginning of the play and its death at the end become symbolic christening the baby serves as a prelude to the renaming of the whole of Ballybeg, and the baby's death foreshadows an ominous, unhappy result of the hybridity brought by the illegal combination of Ireland and England.

5 Friel deliberately disrupts homogeneity and purity with pervasive adulterations in his play - the adulterated language, love, marriage, and birth not only "[undermine] the stable formation of legitimate and authentic identities" ${ }^{5}$ of the characters but also represent a hybrid Ballybeg, an opposite to the nationalist myth of a genuine, homogeneous, and monolithic Ireland. Friel's insistence on hybridity in his play thus dismantles both nationalist and colonialist baggage, for "the processes of hybridization... 
are at every level recalcitrant to the aesthetic politics of nationalism and... to those of imperialism ${ }^{6 "}$.

6 Such recalcitrance to imperialism is best demonstrated in the double presence in Translations - two name systems are used; two types of school coexist; two languages are spoken through one representation. It is true that English colonization aims to supplant Irish language, culture, and tradition with English substitutes, but they only have partial success, for the Irish system is not entirely wiped out but persists in a reduced and marginalized condition. Although the Ordnance Survey renames the whole of Ballybeg, it only produces a dual name system. English names, as the official place names, are put on the map and used by the English officers, while the Irish names are still used by Irish people in their daily lives. That is why Owen has to translate those English names back into their Irish originals to make his people understand Lancey's threats. There is reason to believe that such a duality will finally be eliminated through the English educational system, for the Irish people will not be able to know their Irish place names any more when they are educated in English only. However, given the oral tradition of family education, which is manifest in Owen's knowledge of "Tobair Bhriain" from his grandfather, and the surviving written records, such as the church registry and jury lists Owen uses as references for his name-translations, it is questionable that Irish place names can be completely eradicated. They may gradually fall into disuse, but they will continue their existence not only in memory but also in histories retold from generation to generation. In this way, they are still capable of shaping Irish identity.

7 Uncertainty actually increases when the English educational system turns out to be anything but overwhelming, for hedge schools still remain alongside national schools. Although the National School System, set up in 1831, is said to put an end to the traditional Irish education and accomplish "the eradication of Gaelic Ireland," because "Ireland changed from a predominantly Gaelic-speaking nation to a predominantly English-speaking nation" by $1850^{7}$, it was by no means a sweeping victory. Hedge schools did not disappear from Ireland but retreated to remote places. As the play shows, while Hugh's hedge school is displaced by the new national school, Manus is invited to start a new hedge school on Inis Meadhon, an island south of Ballybeg. School records also show that hedge schools were far from extinct even after 1850: "As late as the year 1866 we find in the Bruree school records such notes as: John Moran, aged 5 of Clogher 'sent to a hedge school held in their own house,' Pat Foley, aged 6, Ballynaught 'sent to a hedge school's." According to P. J. Dowling, the hedge school "was a vital tradition in Ireland until nearly the end of the nineteenth century". The fact that the hedge school can still be "a vital tradition" for almost fifty years in an already Anglicized Ireland undercuts the success of the National School System. The slow exit of the hedge school from Irish society testifies to the tenacious presence of all the native traditions in the face of foreign invasion and replacement. The implementation of the National School System in Ireland is thus shown to be anything but complete and absolute. The coexistence of English names and Irish names, national schools and hedge schools thus demonstrates that Ireland's Anglicization process is inevitably adulterated.

8 Eventually Irish names and hedge schools will pass into oblivion in the predominantly English system, but even then Irish ways of being will still linger on rather than die out as shown in language: the Irish way of speaking has carried over into their acquired speech, English. According to Declan Kiberd, "once Anglicizing is achieved, the Irish and English, instead of speaking a truly identical tongue, will be divided most treacherously by a 
common language ${ }^{10 "}$. Translations exemplifies such a division, for a dual linguistic presence still persists in the play even if English has completely replaced Irish. Although the fact that the play is written in English rather than Irish is itself a testimony to Ireland's full Anglicization, Friel's using English to represent Irish undercuts the seemingly thorough and successful Anglicization: it demonstrates that the English and the Irish are not speaking the same language although they both speak English. In this sense, Translations speaks directly to Bhabha's "colonial mimicry", and its using English to express both English and Irish constitutes a "double articulation ${ }^{11}$ ", which not only puts the audience constantly on the alert for the difference under the sameness, but also enables the Irish characters to disavow English in the very act of speaking it. Therefore, Translations is not a play "about language and, in particular, the death of the Irish language ${ }^{12 "}$; rather, it demonstrates that the Irish way of speaking still continues in English and subverts English from within, for speaking English is mimicry, "simultaneously repetition and difference ${ }^{13}$ ". As the most Anglicized language turns out to be "a difference that is almost the same, but not quite," Ireland's colonial existence is also shown to be "less than one and double ${ }^{14 "}$ ", for there is always Irish residue, difference, and recalcitrance in the process of Anglicization.

9 If English colonization leads to a coexistence of two name systems, educations, and languages, it also brings together two people, whose hybridity, however, is fraught with differences and conflicts. Yolland, as a romantic English officer, is enthralled by Irish culture and lifestyle. Unlike the energetic, ambitious empire-builders such as his father and Lancey, who believe that they are creating a brave new world, Yolland is not an ideal colonial servant. He finds the tranquil Irish life more congenial to his temperament, which makes him want to learn the Irish language and stay in the country. With his genuine longing to know the other culture and people, Yolland breaks the stereotype of the self-centered, arrogant Englishman. However, as he also realizes, his cultural hybridity does not enable him to decode the other culture, for the inherent differences embedded in two cultures cannot be easily transcended through mingling.

10 Yolland and Maire's love best illustrates such intrinsic discrepancy. As the ideal hybridization of the English and the Irish, their love symbolizes "two cultures reaching out to each other, trying to communicate with each other and to understand each other ${ }^{15}$ ". However, such a "perfect" combination is actually full of confusions, cross talking, and misunderstandings. In spite of their similar thoughts and feelings, the ways they approach things and express themselves are so different that most of the time their communication is only a babel of voices. Their lacking in a common language, literally or figuratively, is manifest in their comments on the wet grass - Maire infers from her subjective experience ("The grass must be wet. My feet are soaking"), while Yolland infers from the objective fact ("Your feet must be wet. The grass is soaking") ${ }^{16}$. Sensuous Maire is thus set apart from factual Yolland. By playing up the stereotypical national traits of his characters - the Irish tend to indulge in feelings and senses, while the English are concerned more with facts and reason - Friel shows their inner differences. Their disparity is further exposed at the climactic moment of the play. As Maire and Yolland are brought closer by citing Irish place names together, a real communication seems at hand at last, which, however, turns out to be miscommunication, for "their mutual desire is partly based on misunderstanding ${ }^{17 "}$ ". If their love begins with misconceptions Yolland's fantasy about Ireland and Maire's dream of an outside world - it also ends with their misinterpretation of each other's desires, for Yolland wants to stay ("to live here - 
always - with you"), while Maire wants to leave ("take me away with you, George") ${ }^{18}$. Their disparate intentions and contradictory choices reveal their unbridgeable gap. Yolland and Maire's love, the embodiment of an ideal Anglo-Irish hybridity, is thus shown to be full of inner differences, whose tragic ending further testifies to the gulf between the two cultures.

11 If Yolland loses his life for his hybrid ideal, his Irish counterparts are no less hybridized and tormented in the confluence of two conflicting cultures. As Luke Gibbons warns us, any theorizing on the notion of hybridity in an Irish context must take into account the degree to which that hybridity has been more or less imposed on the colonized by the colonizer ${ }^{19}$. This imposition makes it impossible for the Irish characters to come to terms with their hybridity: they cannot reconcile their Englishness and Irishness, for the colonial antagonism leaves little room for personal ambiguity. Colonization thus not only produces hybridity but also turns it into a deadlock - the Irish characters can neither fully accept nor completely obliterate it. They try to manage their hybridity through negation, resignation, or reconciliation, but their efforts fail to negotiate their warring identities, which condemns them to constant struggle and agony. Read in this light, it is the colonial situation rather than Friel's pessimism that is responsible for the fact that "many of his characters are forced into self-denying or self-destructive paths ${ }^{20 "}$.

Manus and Maire try to purify their adulterated selves as a way out of their hybridization. As a stubborn nationalist, Manus disowns his Englishness by refusing to speak the colonizer's language, and his happy acceptance of the job offer to set up a new hedge school on Inis Meadhon further demonstrates his allegiance to Irish cultural traditions. Although it is far from clear why Manus wants to leave after Yolland's disappearance, his decision to go southwest to county Mayo indicates a further retreat to the hinterlands of Ireland in order to be further away from English control and influence. Since "a physical maiming... is a public representation of their spiritual deprivation ${ }^{21}$ ", Manus's lameness expresses his defective one-sidedness in his denial of hybridity in pursuit of a pure Irish identity. Maire, on the contrary, embraces Englishness as the embodiment of advancement. Believing "the old language is a barrier to modern progress ${ }^{22}$ ", she wants to learn English and emigrate to America. Therefore, "[f]rom the opening of the play, Maire's desires are directed outside Baile Beag'23", which accounts for her welcoming attitude toward the English soldiers and her falling in love with Yolland. Parallel to her admiration of English language, life, and people is Maire's discontentment with and critique of Irish living. Exhausted by the heavy farming and housework, Maire cannot see any future in her poor, hard life. Her active seeking of a new, better life "draws her outside of the community to Yolland...[who] represents the escape she so desperately wants ${ }^{24}$ ". Maire's forsaking Manus for Yolland thus shows her rejection of Irish life in pursuit of an English future. However, Maire's abandonment of Irishness for Englishness is also unsuccessful, for her infatuated love incurs not only tribal punishment but also the colonizer's retaliation. Manus and Maire, in their different ways, fail to comprehend the importance of coordinating Irish tradition and English modernity in colonial Ireland. Such blindness leads them to deny their mixed cultural holdings in favor of an unadulterated identity. However, no matter whether they leave or stay at Ballybeg, they have to deal with their hybridity, for the colonial confrontation has made any opinionated or wishful isolation impossible.

13 Unlike one-sided Manus and Maire, Hugh is a hybrid person. He is first of all a proud, pompous Irish scholar who sings high praise of their "rich language [and] rich literature ${ }^{25}$ 
". Like open-minded Yolland, knowledgeable Hugh also breaks a cultural stereotype. While reversing civilized Englishman and uncouth Irishman through Lancey and Hugh, Friel also shows Hugh's prejudices against English language and literature. Out of contempt for the "plebeian"26" language used mainly "for the purpose of commerce ${ }^{27 "}$ ", Hugh refuses to teach Maire English. Although mainly a scholar, Hugh also has his revolutionary moments: he marched to join the 1798 rebellion when he was young, and when he is drunk, he roars at English soldiers "Visigoths! Huns! Vandals ${ }^{28}$ !", venting his indignation against English colonizers, who not only invade Irish territory but also destroy Gaelic civilization. With all of his Irish pride and sentiments, Hugh still has his English side. Knowing that the Anglicization of Ireland is unavoidable, Hugh does not resist it but adapts himself to it quickly. He applies for the position at the new National School; he courteously welcomes English officers, acquiesces to their military operations in Ballybeg, and offers them not only drinks but also "our friendship, our hospitality, and every assistance that you may require ${ }^{29 "}$; he speaks English in the presence of English officers; before the play ends, he also agrees to teach Maire English.

From his previous refusal to his final agreement to teach English, Hugh shifts from an Irish culturist to a colonial hybrid, a result of his realization that "a civilization can be imprisoned in a linguistic contour which no longer matches the landscape of... fact ${ }^{30 "}$. Fascinated with the Irish language, Hugh does not lose his vision but gains valuable insights. He is not only aware that their colorful language is actually an illusory and selfdeceptive compensation for their impoverished reality but also clear about the necessity of change: as their rich and ornate heritage fails to advance their society, their ancient Gaelic civilization has to give way to a modern English civilization. Like Irish words, their old civilization is "not immortal 11" but needs to be renewed constantly, "because once we [cease renewing it], we fossilize ${ }^{32 "}$. As Ireland's Anglicization becomes an enforced yet necessary cultural renewal, teaching English becomes Hugh's first step to domesticate the English language for the Irish home. While acknowledging the importance of appropriating English, Hugh is not blind to the inherent differences between English and Irish, for English vocabulary and grammar may not help people "to interpret between privacies ${ }^{33}$ " and "will not necessarily ensure accurate translation, nor establish real communication $^{34 "}$ ", which once again testifies to the discrepancies and conflicts embedded in cultural hybridity.

Although Hugh's Englishness and Irishness seem reconciled in his acceptance of a hybridized Ireland, such reconciliation is actually based on fatalism. Hugh tries to read Ireland's colonization as a fated, historical course it has to run, the same course Virgil sets down for Carthage in the Aeneid. As Trojan blood (Rome) is predestined to overthrow Tyrian towers (Carthage), England is also destined to rule over Ireland - "such was the course ordained - ordained by fate ${ }^{35 "}$. While Hugh seeks consolation in Virgil, ironically, Virgil's Aeneid is "itself an extraordinary work of cultural appropriation and 'translation' of Homer's Odyssey" ${ }^{36 "}$ and "Virgil wrote the Aeneid not to lament the destruction of Carthage but to celebrate the triumph of Roman civilization ${ }^{37 "}$. Likewise, the Latin Hugh keeps using is also a conquering language. Although all these seem to demonstrate "a fatalistic inevitability about the domination of the conqueror's language ${ }^{38 "}$ ", they also doom Hugh's attempts to take any comfortable refuge in them. As the conqueror's language and literature, they magnify rather than allay Hugh's agony at being conquered. No wonder Hugh stammers when he recites a passage from the Aeneid about the downfall of an earlier civilization. His search for shelter in resignation proves futile, for his 
threadbare fatalism cannot really relieve him of his colonial affliction. As a result, the play ends with an inconsolable Hugh, still suffering from his confusing, hybridized condition.

16 If Hugh develops from an Irish chauvinist to an Anglo-Irish hybrid, Owen moves in the opposite direction. He starts out as a mediator between the English and the Irish, but ends up as a potential Irish nationalist. As his efforts to reconcile the two cultures and people through translation are frustrated by the colonial antagonism, and his own borderland ambiguity is forbidden in tense military conflict, the most hybridized person in the play has to give up his hybrid ideal and take one side. Many critics overlook Owen's hybridity by dismissing him as a hireling who serves the English army for his own benefit. But this is a reductive view, for it explains neither his intimate friendship with his English employers nor his unusual enthusiasm for translation. More importantly, it prevents us from seeing Owen position himself as a middleman between two languages, cultures, and people. As a person living in the most Anglicized Irish city - Dublin - for six years, Owen naturally befriends the English and uses his bilingual privilege to mediate between them and his own people. Although his good-willed yet inopportune mediation does more harm than good due to his ignorance and naivety in politics, his attempts at reconciling the warring sides should be acknowledged.

Owen's hybridity is explicit from the different roles he plays: he is the son of Hugh, brother of Manus, and a native of Ballybeg, but at the same time he is also the friend of Lancey and Yolland, and the interpreter of the English army. In spite of his six-year absence from Ballybeg, Owen is able to resume the old intimacy with Ballybeg people immediately. Feeling at home in Ballybeg, Owen is nevertheless Anglicized to a great extent. Smartly dressed and speaking English, he is on first name terms with English officers. With his dual performance, "Owen clearly shares roots with the company onstage but at the same time looks an outsider ${ }^{39}$ ". Such a duality is also represented by Owen's double names: Irish name Owen, English name Roland. Owen's acquiescence to his wrong English name seems to indicate his acceptance of an English identity. The similarity of the two names - Roland and Yolland - also suggests an intimate relationship between Owen and Yolland. If Manus is Owen's biological Irish brother, Yolland can be regarded as his cultural English brother. Owen's hybrid identity is thus established not only through his dual names but also through his parallel relationship with Manus and Yolland.

18 Hybrid himself, Owen also functions as the "go-between ${ }^{40 "}$ to reconcile the English and the Irish through his translations - he not only translates the languages but also tries to patch up the differences, bridge the gaps, and establish a certain connection, communication, or understanding between the opposing sides. However, Owen is only "one of those ineffectual men-in-the middle...whose attempts at mediation are ultimately fatuous ${ }^{41}$ ", because his illusory belief in Anglo-Irish friendship, blind faith in English norms, and unrealistic ideal of cultural exchange have doomed all his translations, which do not bring the two languages, cultures, and people together but impose colonial control and cultural deprivation on Ireland. Ignorant of the loaded colonial oppression in the seemingly innocent map-making, Owen, the well-intentioned mediator, unwittingly becomes the colonizers' instrument and accomplice.

19 As a matter of fact, Owen's translations have taken both English and Irish sides into consideration. Viewing himself as the friend and helper to his English employers, Owen prettifies Lancey's description of the Ordnance Survey to make it more acceptable to the 
Irish people. By omitting and distorting the colonial content in Lancey's speech, Owen

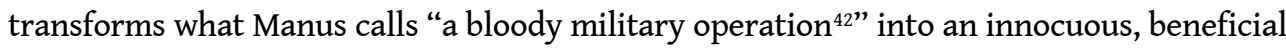
civil project. Similar consideration also exists in his translation of Irish place names for the new English map, for he "anglicize[s] names with greater 'deference to the Irishness of Irish place-names"' and keeps those English names "Irish in character ${ }^{43}$ ". By searching for the English words which have the most similar sound and meaning to the Irish names, for example, "Burnfoot" for "Bun na hAbbann," and "Duff" for "Dubh," he tries to establish a connection, find some common ground, and convey shared ideas between Irish and English, or in Declan Kiberd's words, to "carry over aspects of Gaelic culture into English ${ }^{44 "}$.

20 However, Owen's conscientious translations cannot do real justice to Irish names. In spite of his painstaking efforts, many Irish names still remain untranslatable, which renders their English equivalents random and arbitrary. Moreover, as "language does not merely exist as a self-contained linguistic enterprise...[but] exists...as a network of cultural encodings ${ }^{45}$ ", all of the Irish names are closely related to the Irish history, culture, and traditions, and it is impossible to translate all of their implications into another language. Therefore, Owen's translations cannot "carry the same wealth of association, the same connotations, the same emotional resonances ${ }^{46 "}$ as their Irish originals, and renaming becomes "an eviction ${ }^{47}$ " of Irish cultural and historical significance. Contrary to his attempts to establish connection, Owen perpetuates disconnection.

21 Moreover, Owen's unforgivable naivety and insensibility to politics also doom all of his efforts at reconciliation. He fails to see that his translations do not benefit Irish people as a cultural exchange but aggravate their colonized condition, for renaming further dispossesses Ireland and strengthens England's dominance geographically, culturally, and militarily. The English do not care whether his translations truthfully reflect Irish originals as long as they are effective as a means of control. Therefore, no matter how "accurately and sensitively ${ }^{48}$ " he translates, Owen is not bridging two cultures for a mutual understanding but imposing one on the other and enabling the colonizers to master and penetrate the colony more efficiently. In this sense, Owen's translations actually backfire on him.

If Owen tries to negotiate the English and the Irish in his previous translations, his last translation proclaims their irreparable rupture. Lancey's sudden coldness towards Owen after Yolland's disappearance shows the demise of their friendship in Anglo-Irish conflict, and his announcement of a ruthless eviction of Ballybeg further shocks Owen into the reality of hostility and antagonism. In this way, "Owen, who had mistakenly thought he could mediate between the two communities, is forced to translate Lancey's threats of violent retaliation...This time, his translation no longer seeks to conceal the brutal violence that lies behind the official jargon ${ }^{49}$." Repeating the threats helplessly, Owen realizes his futile role of go-between in colonial Ireland. Translation is not friendly exchange as he naively believes but enforced displacement, which does not promote mutual understanding but entrenches discord. Like the tragic love between Yolland and Maire, Owen's failed translations further testify that any romantic, idealized conception of colonial hybridity is a misconception.

Colonial conflicts not only frustrate Owen's cultural translations but also forbid his personal ambivalence, which forces Owen to make an either-or choice between his English and Irish self. Therefore, we witness Owen's transformation "from being a gobetween and interpreter, mediating...between two causes,... to [taking] sides ${ }^{50 "}$. His initial 
indifference towards his wrong name Roland changes to a reclamation of his proper name Owen, which cuts out his Englishness and reasserts his Irish identity. As his understanding of the renaming project increases, his attitude towards it also changes from unthinking acceptance to deliberate resistance: he quits his job and discards the Name-book; he admits his translation is "a mistake ${ }^{51}$ "; he gives Irish place names when questioned by Lancey. In this way, Owen renounces all his unwitting collaborations in English colonization. Moreover, the play also implies that Owen may join the Donnelly twins in their resistance against the English, and his lying about Manus to Lancey can be regarded as his initial revolt. From his translation to transformation, Owen demonstrates that no reconciliation is available for the colonial hybrid, who is condemned to a life-long struggle between two clashing cultures.

As a matter of fact, the play's title has epitomized the theme of hybridity. To translate, there must be something to translate from, and given the untranslatable residue elaborated in Homi Bhabha's The Location of Culture as well as George Steiner's After Babel, translation itself implies a double, different, and conflicting existence. If we take all the translations in the play - the place names, schools, languages, and people - into consideration, we can see that they do not lead to identity but hybridity: there is the underlying, tenacious Irish presence in an anglicized society, the subversive colonial mimicry in Irish English, and the characters stuck in an eternal borderland yet unable to come to terms with their adulterated selves. By choosing colonial hybridity as the subject matter of his play, Friel eschews both nationalist and imperialist agendas. Knowing "there were certain inadequacies within the original culture that unfitted it to survive the impact of the English presence and domination ${ }^{52 "}$, Friel shows no nostalgia for the lost Celtic past and accepts the "hybrid Anglo-Irish heritage ${ }^{53 "}$. However, Friel also makes it clear in his play that such a hybrid heritage is a product of English colonization, which not only accounts for all the disparities, conflicts, and sufferings inherent in Irish hybridity but also answers for the irresolvable plight Irish hybrids find themselves in they can neither escape nor embrace their hybridity, which condemns them to an everlasting struggle. In this way, Friel successfully translates Irish hybridity into a colonial dilemma.

\section{NOTES}

1. Ulf Dantanus, Brian Friel: A Study. Faber and Faber, London and Boston, 1988, p. 195.

2. Tony Corbett, Brian Friel: Decoding the Language of the Tribe, Ireland, The Liffey Press, 2002, p. 93.

3. Richard Pine, The Diviner: The Art of Brian Friel, Dublin, University College Dublin Press, 1999, p. 343.

4. Scott Boltwood, Brian Friel, Ireland, and The North, Cambridge University Press, 2007, p. 155. 
5. David Lloyd, "Adulteration and the Nation." Postcolonial Discourses: An Anthology, Ed. Gregory Castle, Blackwell Publishers, 2001, p. 418.

6. David Lloyd, "Adulteration and the Nation", Postcolonial Discourses: An Anthology, Ed. Gregory Castle, Blackwell Publishers, 2001, p. 422.

7. F. C. McGrath, Brian Friel's (Post)Colonial Drama: Language, Illusion, and Politics, Syracuse University Press, 1999, p. 180.

8. "De Valera's Bruree School Was 100 Years Old in 1963" at www.irishidentity.com.

9. Richard Harp quotes from P. J. Dowling's The Hedge-Schools of Ireland (Cork, Mercier Press, 1968) in his "Manus and Oedipus the King", A Companion to Brian Friel. Ed. Richard Harp and Robert C. Evans. West Cornwall, CT, Locust Hill Press, 2002, p. 26.

10. Declan Kiberd, Inventing Ireland, London, Jonathan Cape, 1995, p. 622.

11. Homi Bhabha, The Location of Culture, Routledge, First Edition, 1994, p. 86.

12. Nesta Jones, Brian Friel, Faber and Faber, London and New York, 2000, p. 57.

13. Homi Bhabha, The Location of Culture, Routledge, First Edition, 1994, p. 112.

14. Ibid., p. 86, p. 120.

15. F. C. McGrath, Brian Friel's (Post)Colonial Drama: Language, Illusion, and Politics, Syracuse University Press, 1999, p. 186.

16. Brian Friel, Translations. Selected Plays (Irish Drama Selections 6), The Catholic University of America Press, Washington, D. C., 1984, p. 426.

17. Lauren Onkey, "The Woman as Nation in Brian Friel's Translations." Brian Friel: A Casebook, Ed. William Kerwin, New York and London, Garland Publishing, Inc., 1997, p. 165.

18. Brian Friel, Translations. Selected Plays (Irish Drama Selections 6), The Catholic University of America Press, Washington, D. C., 1984, p. 429-30.

19. Luke Gibbons, Transformations in Irish Culture, Notre Dame: University of Notre Dame Press, 1996, p. 176.

20. Tony Corbett, Brian Friel: Decoding the Language of the Tribe, Ireland, The Liffey Press, 2002, p. 33.

21. Brian Friel, Brian Friel: Essays, Diaries, Interviews: 1964-1999. Ed. Christopher Murray, Faber and Faber, 1999, p. 87.

22. Brian Friel, Translations. Selected Plays (Irish Drama Selections 6), The Catholic University of America Press, Washington, D. C., 1984, p. 400.

23. Lauren Onkey, "The Woman as Nation in Brian Friel's Translations", Brian Friel: A Casebook, Ed. William Kerwin, New York and London, Garland Publishing, Inc., 1997, p. 163.

24. Ibid., p. 165.

25. Brian Friel, Translations. Selected Plays (Irish Drama Selections 6), The Catholic University of America Press, Washington, D. C., 1984, p. 418.

26. Ibid., p. 417.

27. Ibid., p. 399.

28. Ibid., p. 435.

29. Ibid., p. 407-408. 
30. Ibid. p. 419. Friel quotes from George Steiner's After Babel: Aspects of Language and Translation (Oxford, New York, Oxford University Press, 1992).

31. Ibid., p. 419.

32. Ibid., p. 445.

33. Ibid., p. 446.

34. Richard Jones, "Dramatic Interpretation as Theatrical Translation: Friel's Adaptations of Chekhov", A Companion to Brian Friel, Ed. Richard Harp and Robert C. Evans. Locust Hill Press, 2002, p. 109.

35. Brian Friel, Translations. Selected Plays (Irish Drama Selections 6). The Catholic University of America Press, Washington, D. C., 1984, p. 447.

36. George O'Brien, Brian Friel. Twayne Publisher, Boston, 1990, p. 108.

37. F. C. McGrath, Brian Friel's (Post)Colonial Drama: Language, Illusion, and Politics, Syracuse University Press, 1999, p. 195.

38. Ibid., p. 195.

39. Nesta Jones, Brian Friel. Faber and Faber, London and New York, 2000, p. 84.

40. Brian Friel, Translations. Selected Plays (Irish Drama Selections 6), The Catholic University of America Press: Washington, D. C., 1984, p. 408.

41. Richard Harp, "Manus and Oedipus the King", A Companion to Brian Friel, Ed. Richard Harp and Robert C. Evans, West Cornwall, CT, Locust Hill Press, 2002, p. 25.

42. Brian Friel, Translations. Selected Plays (Irish Drama Selections 6), The Catholic University of America Press, Washington, D. C., 1984, p. 408.

43. Scott Boltwood quotes from J. H. Andrews's, A Paper Landscape: The Ordnance Survey in Nineteenth-Century Ireland (Oxford, Oxford University Press, 1975, p. 122) in his Brian Friel, Ireland, and The North, Cambridge University Press, 2007, p. 159-60.

44. Declan Kiberd, Inventing Ireland, London, Jonathan Cape, 1995, p. 624.

45. George O'Brien, Brian Friel, Twayne Publisher, Boston, 1990, p. 105.

46. Martine Pelletier, "Translations, the Field Day debate and the re-imagining of Irish identity", The Cambridge Companion to Brian Friel, Ed. Anthony Roche, Cambridge University Press, 2006, p. 69.

47. Brian Friel, Translations. Selected Plays (Irish Drama Selections 6), The Catholic University of America Press: Washington, D. C., 1984, p. 420.

48. Ibid., p. 420.

49. Martine Pelletier, "Translations, the Field Day debate and the re-imagining of Irish identity", The Cambridge Companion to Brian Friel, Ed. Anthony Roche, Cambridge University Press, 2006, p. 67.

50. Ulf Dantanus, Brian Friel: A Study. Faber and Faber, London and Boston, 1988, p. 191.

51. Brian Friel, Translations. Selected Plays (Irish Drama Selections 6), The Catholic University of America Press, Washington, D. C., 1984, p. 444.

52. Seamus Heaney, "Review of Translations." Times Literary Supplement, 24 Oct., 1980, p. 1199.

53. F. C. McGrath, Brian Friel's (Post)Colonial Drama: Language, Illusion, and Politics, Syracuse University Press, 1999, p. 197. 


\section{ABSTRACTS}

This paper is about the colonial hybridity in Brian Friel's Translations, which goes under the surface of the loss of Gaelic civilization due to English cultural colonization, and examines the coexistence of two incompatible cultures and the cross-fertilization of two opposing peoples in the process of Ireland's Anglicization. If the double presence of English and Irish civilizations (e.g. place names, schools, and languages) inevitably hybridizes the characters, the tense colonial antagonism also condemns their hybridity to irreconcilable conflicts and contradictions.

Cet article analyse l'hybridité coloniale dans Translations de Brian Friel, qui dépasse le simple constat du déclin de la civilisation gaélique dû à la colonisation par la culture anglaise, et prend en compte la co-existence de deux cultures incompatibles et l'influence mutuelle entre deux peuples opposés à travers le processus de l'anglicisation de l'Irlande. Si la double présence des civilisations anglaises et irlandaises (c'est-à-dire les noms de lieux, les systèmes éducatifs, les langues) rend inévitablement les personnages hybrides, l'antagonisme colonial aigu condamne aussi leur hybridité à des conflits et des contradictions irréconciliables

\section{INDEX}

Keywords: Friel Brian, Anglo-Irish relations, drama, imperialism/colonialism

Mots-clés: théâtre, impérialisme/colonialisme, relations anglo-irlandaises

\section{AUTHOR}

\section{CHU HE}

Indiana University South Bend 